\section{A HUNDRED YEARS OF ANTHROPOLOGY IN BRITAIN}

\author{
By $S_{i R} J O H N$ MYRES, O.B.E., F.B.A.
}

$\mathrm{T}$ HOUGH the Royal Anthropological Institute was not founded until 1871 , it is the direct suecessor of the Ethnological Society of 1843, after amalgamation with the Anthropological Society of 1863, and may justly claim now to celebrate, on October 30, the centenary of the organized study of man in Great Britain; and the main turning-points in the careers of these Societies illustrate the general course of events in a wide range of studies, from comparative anatomy of the principal human varieties to comparative religion, sociology and linguistics, and the whole range of the material arts with their archæological perspective, so nearly co-extensive with human palæontology.

At first sight this study of man is no systematic science, like chemistry or physiology, but rather analogous to geology and geography, which combine the methods and the data of more specific branches of knowledge for the elucidation of problems of a secondary order, and especially involving relations of distribution in time and space. But it has been charaoteristic of British anthropology to insist that the peculiar nature of man provides the same kind of common basis and definition for a coherent mass of information, and systematic study of this material by every available means, as the earth provides in geography - and not least because in geography, too, it is 'the earth as the abode of man' which seems to many geographers to differentiate between this study and geology or terrestrial astronomy. American anthropology has followed the same line of thought and development; partly because in the New World, as in the British Empire, there has been so great a wealth of opportunity for the regional study of more or less self-contained and self-determined varieties of mankind, so that analytical studies of structure, language, material and social equipment have been continually challenged and tested by fresh discoveries in the field; whereas in most European countries, less well provided with 'aborigines', the special sciences which contribute to the study of man have developed independently, and lost this common basis of humanity. It is also this common objective, which has given to much British and American work a disciplinary and educational value, and thus has at long last determined the position and function of the principal anthropological institutions and schools, as the outline of an academic discipline which might claim in due time to be Literae humanissimae.

Though both physical anthropology and the elements of ethnology, and what is sometimes distinguished as cultural anthropology, had long been studied discursively, in classical culture, and from the Revival of Learning, there were many convergent instigations to more systematic treatment in the early years of the nineteenth century. The Romantic Movement, and the Revolutionary Movement which emerged from it, gave the same impulse to human studies as to the physical sciences. In both the cry was 'back to Nature', at whatever cost to convention or authority. Anatomical studies reformulated old problems of the origin and significance of human races and varieties. Comparative philology indicated. processes of modification and replacement among languages, and relations of heredity kotween them. seductively like those of a pedigree, and sometimes correlated regionally with major racial types, Semitic with Arab, and the like. The Danish archæologists combined typological classification of implementsstone, bronze, and iron-with the stratigraphy of the peat bogs where they were found, and especially with secular changes of flora and climate. Cave-finds in France and in England associated rude implements with 'ante-diluvial' fauna, and even with human remains. Comparative mythology, in dangerous alliance with philology, led on to the interpretation of social and political terms in kindred languages, to a comparative sociology, and to a 'linguistic palæontology'. The common factor in all these new studies was the notion of development and series of events in time.

There were other considerations, more practical and controversial; the abolition of slavery was a corollary of the Rights of Man within one human species. But what if, zoologically, there was more than one human species, of separate special creation and independent 'place in Nature', like that of the domesticable animals, over whom human dominance seemed to have biblical sanction. Was not black man, in fact, the 'natural slave' as defined in Greek philosophy? To some, the American Indian seemed. to present a similar problem, as the economic expansion of the West went on. On both sides zoological arguments were brought in, to support philanthropy or to challenge vested interests, and it was long before this kind of 'applied anthropology' became obsolete.

There was also the practical question: What was to be done with the 'black brother' after emancipa. tion? Was he improvable into something not so far from white? What was the relation between physical and mental characters in man, and what could be done to perfect Nature's work by scientific processes ? It is significant that most of the early British anthropologists were practising medical men, and James Cowley Prichard, the most eminent, was a Commissioner in Lunacy, with a high repute in questions of the moral and legal responsibility of the insane. Several were also members of the Society of Friends, and Thomas Hodgkin was the founder of the Aborigines' Protection Society in 1838. Other philanthropic agencies, the Negro Emancipation Soeiety and the British Africa Colonization Society (both of 1834), collected information and used it as best they could. Another foster-parent, for obvious reasons, was the British Phrenological Society.

The earlier history of the Ethnological Society has been so fully told elsewhere that only essentials are necessary here. It was never a populous or influential body, and owed its existence and successes to a small group of original and devoted men, nearly all in professional careers, and very few of them affluent. On many occasions the same persons appear as the active members of the geographical or zoological section of the British Association, sometimes in a specific subsection for ethnology; and this summer and winter partnership, never quite effected in any other section, makes the origin of some enterprises difficult to trace, except personally.

In 1839 Prichard addressed to the British Association a warning, already needful, on "The Extinction of some Varieties of the Human Race", and appealed for prompt and organized effort to record this vanishing material. It was the first of a long series of such appeals, to forestall both the disappearance of aboriginal communities altogether, and the no less fatal effects on aboriginal customs, of contact with colonists, traders, and missionaries. For the guidance 
of intending travellers and of observers already in contact with natives, the British Association appointed a committee to draft a pamphlet of "Instructions to Travellers", in which the whole programme of anthropological and ethnological research was set forth : an original and stimulating directory, and the immediate predecessor of the wellknown "Notes and Queries in Anthropology" which have for many years been printed and reprinted by the British Association, but sold, and distributed to travellers, by the Anthropological Institute. It was the first example of a type of handbook of which the most famous is the Royal Geographical Society's "Hints to Travellers".

On June 22, 1842, Prichard again addressed the British Association "On the Relation of Ethnology to other Branches of Knowledge", with the outline of an inclusive programme of advanced study and objectives for research; and on July 20 the prospectus was issued for an Ethnological Society, signed by Richard King (1811-76), a pupil of Thomas Hodgkin at Guy's (M.R.C.S. 1832 and hon. M.D. of New York), who had been surgeon-naturalist to Capt. George Back's expedition to the Great Fish River (1833-35), and published a book on the Eskimo in 1844. The first meeting was held early in November, 1843, with King as secretary and Admiral Sir Charles Malcolm (1782-1851) as president. Malcolm had been superintendent of the Bombay Marine, the precursor of the Indian Navy; he had created a distinguished school of surveyors, and devoted much of his leisure to the Royal Geographical Society and to the organization of charities. Meetings were held in Hodgkin's house in Bedford Square, London, and in hired rooms at 27 Sackville Street, W., and both Hodgkin and Prichard seem to have been generous financially. The latter published his "Natural History of Man" in 1843, and died in office as president in 1848. Another good friend was James Crawfurd (1783-1868), who had used the opportunities of a medical career in India and Malaya and returned, home in 1827 to devote himself to Oriental languages.

King returned to arctic exploration in 1850 , wrote an inclusive account of the long search for Franklin (1855), published an account of the Lapps (1871), and lived to be a member of the first council of the Anthropological Institute.

Another pioneer, on rather different lines, was Robert Knox (1791-1862), who graduated in medicine at Edinburgh in 1814, served as army surgeon at Waterloo, studied in Paris under Cuvier (1769-1832) and Geoffroy E. Saint-Hilaire, and organized the Museum of the Royal College of Surgeons at Edinburgh (1825), collecting material under the adventurous conditions of the time. Passionate and heterodox, he gravely damaged his own prospects; he lectured volubly on the "Races of Man" in many places, and wrote copiously in the Press, rendering much erratic help to the Society, and became in 1860 an honorary fellow and honorary curator of its museum. He held strong polygenist views but deemed the origin of races to be beyond human inquiry. His influence, therefore, waned when Darwinian evolution was popularized.

Very different are two anthropological pioneers of the next decade. John Beddoe (1826-1911), of Bridgnorth, graduated in medicine from University College, London (1851), and studied in Vienna. Hospital service at Renkioi in the Crimean War extended his earlier studies of hair and eye colour
(1846) to Mediterranean peoples, which he continued to observe in Bristol and Cardiff when he went into general practice. His massive material on "Stature and Bulk of Man in Great Britain and Ireland" (1870), and "The Races of Britain" (1885) has been supplemented but not replaced, especially by the British Association's Ethnological Survey Committee and Anthropometric Committee. He was an early and active fellow of the Ethnological Society and a foundation member of the Anthropological Society, and it was under his presidency of the latter (1869-71) that the schism was reconciled and the Anthropological Institute inaugurated.

George Rolleston (1829-8I), combining classical scholarship with anatomical distinction, served, like Beddoe in the Crimean War, and as Linacre professor of zoology at Oxford amassed a valuable collection of crania, submitted his system of brain-classification to the British Association at Oxford (1860) and supported Huxley in opposition to Owen at Cambridge in 1862. His Royal Institution lecture (June 24, 1862 ) is another turning point. With William Greenwell ("British Barrows", 1877), he established the racial history of Britain on the same sure foundations as the racial distributions outlined statistically by Beddoo.

But the leading mind in ethnology during the Darwinian period was that of Thomas Henry Huxley (1825-95), whose learning, judgment, and skilled advocacy made him a second founder of the science in Britain, and moreover the leading spirit in an 'evolutionary' movement far outranging his own anatomical and zoological contributions. The notion of natural selection and survival of the fittest was applied to arts and crafts by General Pitt Rivers, to archæology by John. Evans and Augustus Franks, to institutions by John Lubbock, above all in traditions, ideas and beliefs by Edward Tylor, whose establishment at Oxford (1883), through Rolleston's influence, was the first academic recognition of the new study of man.

The practical issue of American slavery revived old controversies and gave scope to the enthusiasms of James Hunt (1832-69), who joined the Ethno. logical Society in 1856 and was its secretary during 1859-62. Fresh light on the origin of man came from the palæolithic discoveries of Boucher de Perthes, verified by Prestwich and John Evans in 1859; the Neanderthal skull had been found in 1857, and the cave of Aurignac was opened in 1860. But Hunt's enthusiasm failed to rouse the Ethnological Society, and in 1863 he founded the Anthropological, edited the Anthropological Review, and published translations of Waitz and Gerland, the leading ethnologists in Germany, and of Gastaldi on Swiss and Italian lake dwellings. The Anthropological Society loved discussions and ranged far afield, to woman's rights, the Irish question, and above all the Negro question. Its first chairman was Sir Richard Burton. Hunt defended slavery, on the old zoological ground of a plurality of species, at the British Association in 1863, where with Huxley's support a subsection was established for anthropology in 1866 under Section D (Zoology). But Hunt was combative and difficult; he resigned the presidency of his Society in 1867 , but remained its 'director' until his premature death in 1869.

The way was now open for reconciliation. The Negro question had been settled by the American Civil War; Huxley in the chair of the Anthropological Society, and Beddoe of the Ethnological, rallied men of goodwill on all sides, and in 1871 was 
established the Anthropological Institute of Great Britain and Ireland with Sir John Lubbock as its first president. With the financial help of the British Association, the revised "Notes and Queries in Anthropology" were published; the Anthropometric Committee of 1875 gave much needed definition to physical anthropology; and its annual measurements of the members of the British Association did much to popularize statistical treatment of its problems. Organized by Francis Galton, this was the precursor of the Galton Laboratory at University College, London, and of the systematic study of biometry and eugenics in Britain.

When the original library and museum, at $4 \mathrm{St}$. Martin's Place, W.C.2, were pulled down, the good offices of the president of 1883-85, William Henry Flower, secured an appropriate home in the upper part of the Zoological Society's house at 3 Hanover Square. This arrangement, however, was nearly disastrous to both institutions, for the weight of exhibits from the first excavation of Stonehenge (1901-2) irretrievably damaged the building and hastened the transfer of the Zoological Society's offices to Regent's Park. By this time the close association of the Institute with the ethnological staff of the British Museum, inaugurated by Augustus Franks and extended by Charles Hercules Read and others down to the present time, drew the Institute into a succession of abodes in Bloomsbury, the last of which, 21 Bedford Square, is within a few yards of the original meeting room in the house of Thomas Hodgkin.

Of the mature work of the Institute only outlines are possible here. Like its predecessors, it has never been rich, and has owed much to benefactions supplementary to its normal income; from the Carnegie Trustees for the improvement of its valuable library, from the Rockefeller and Laura Spelman Rockefeller Foundations to maintain its Journal, and from other friends for a few small expeditions. But it has never had the popular appeal of the Zoological or the Royal Geographical Society, or the support of academic or industrial interests. Side by side with its proper business of the promotion and publication of research, it has never ceased to urge on the Colonial Office and other public agencies the pressing need for expert acquaintance with the customs and mode of life of the native peoples of the British Empire; but until recently with disappointing response, in comparison with stately institutions such as the Colonial Institutes of the Netherlands and of Belgium, and the Bureau of Ethnology in Washington. Even the urgent task of recording institutions and modes of life which have been fading away before our eyes has been postponed irretrievably. The inevitable dissipation of energies in specialist societies has been minimized by the establishment of research committees within the Institute itself, for India, Africa, Anthropometric Standards, and the like, and of a Joint Committee for Anthropological Research and Teaching, on which universities and independent institutions are entitlod. to be represented, which has no parallel in other branches of learning in Great Britain. In the generation following the war years 1914-18, as the spokes. man of that Joint Committee, the Anthropological Institute has twice taken decisive part in the organization of the International Congresses for Prehistoric and Protohistoric Sciences (London 1932, Oslo 1936) and for Anthropological and Ethnological Sciences (London 1934, Copenhagen 1938), which have provided at least the constitutional foundations for worldwide co-operation on liberal lines in time to come.

\section{ACTIONS OF DRUGS}

$\triangle$ BOUT two hundred and fifty persons attended A a discussion in London on September 24 organized by the Faraday Society and entitled "Modes of Drug Action". The meeting lasted six hours and a wide ground was covered by the papers, which had been circulated in proof. These papers contained much interesting matter and it was perhaps unfortunate that too large a proportion of the available time and energy of the meeting was devoted to listening while they were expounded. In the following account the order in which the papers were given has been altered.

Prof. E. K. Rideal, who took the chair, paid a tribute to Sir William Hardy, who was responsible for initiating these joint discussions between biologists and physical chemists. Sir Henry Dale, in his general introduction, stressed the complexity of the problems of pharmacology and warned the meeting against the optimistic adoption of simple theories to explain complicated facts. Most of the generalizations that have been made have exceptions, and it is on these that attention should be focused.

Prof. J. H. Gaddum discussed the antagonism of drugs, and the quantitative relations between the antagonists. It is important to distinguish two kinds of interaction, both of which may give rise to graded antagonism over a wide range of concentrations. Some antidotes neutralize poisons by forming inert compounds with them, as SH- compounds do with mercury. In this case the study of the antidote throws no light on the action of the drug on the tissue. Its action is merely to reduce the concentration of free poison present.

Other antidotes act by competing with poisons for chemical groups essential to living tissues. The study of these is more interesting, since it allows drugs to be classified according to their antagonists, and may provide evidence about the particular chemical processes in the cell with which the drugs interfere. The work of Woods on the antagonism of sulphanilamide and para-aminobenzoic acid is a striking example of work in this field. The quantitative relationships between antagonists were discussed. If the reactions are of the first order, the ratio of the concentrations of the two drugs which together produce a given effect should be constant, provided that the concentrations of one drug are calculated as differences from the threshold concentration. This is true whether the drugs neutralize one another or compete, so that it is impossible to distinguish the two kinds of antagonism except from independent evidence that the drugs either combine with one another or have molecules which would be likely to combine with similar groups in the tissues.

Dr. H. R. Ing discussed the theory that drugs combine with specific receptors in tissues and the extent to which it can be used to interpret the relation between chemical constitution and pharmacological action. When a series of allied drugs is studied, it is often possible to recognize pharmacodynamic groups which appear to be essential for one particular type of action. It might be said that this group is essential for combination with the receptors, but there are anomalies. The same pharmacodynamic group is commonly present both in active drugs and in their antagonists. The results can be explained in terms of competition between the two drugs for the receptors, if it is assumed that one of them causes an active response and the other blocks the receptors 